\title{
Lost years of a nomad: Exploring Indian experience in Nuruddin Farah's oeuvre
}

To honor Nuruddin Farah's fifty-year-long writing journey, this article explores his time in India (1966-69) and the influence it had on making him a leading postcolonial writer. My approach is largely biographical. I begin with his decision to turn down a scholarship at an American University, which some critics view as immature or even eccentric. I challenge this view of his choice instead to enroll for a degree in philosophy, literature and sociology at the Government College of Panjab University at Chandigarh in 1966 and to make what was then a country of poverty and even famine his first diasporic destination. I argue that this was a well-thought-out, politically correct and wise decision in the global context of international relationships in the 1960s. I also explore Farah's brief association with Indian culture and the knowledge he acquired of Indian philosophy and literature to explain his decision to adopt a feminist perspective to write on injustice against women and the powerless and religious intolerance rather than focus on issues such as independence realpolitik like leading African writers at the time. His first manuscript, published in 1970 as From a Crooked Rib, was a Penguin modern classic by 2004. I argue that this novel was importantly shaped by his Indian experience. I also explore the influence of two novels on the young Farah, on his personal life, ideology and writing even before he went to India: W. Somerset Maugham's novel The Razor's Edge (1944) and Thakazhi Sivasankara Pillai's classic Chemmeen (1956). This is the first substantial investigation of the effect of Farah's Indian experience. Keywords: biographical criticism, Indian experience, nomad, cosmopolitan.

When he was a schoolboy, long before Somalia gained its political independence from Britain and Italy, Nuruddin Farah Hasan (1945-) dreamt of becoming a writer. He is now about to celebrate the golden jubilee of his career as a writer. To date, Farah has published fourteen novels, a non-fiction book and several plays. He was named after a prince in One Thousand and One Nights. When he was being interviewed by Ahmed I. Samatar in 2001, he revealed that he used to delight in cutting out the name "Nuruddin" from pages in One Thousand and One Nights and gluing the small pieces of paper onto the cover pages of his exercise books (Samatar 87). He also enjoyed giving the animal characters in his English language textbooks human names and attributes. His linguistic talent was evident from an early age. As is well known, Farah assisted his mother to compose buraanbur or Somali oral poetry that is sung during social celebrations and community rituals. By the time he was a teenager, he was able to converse equally well in five languages: Somali, Arabic, Amharic, Italian and English. However, Farah found the local education system disappointingly alien. He comments sadly that "the textbooks we were taught from, belonged in the mind and culture of other people" ("Why I Write" 3). Though the mind and culture of "other people" initially shaped the vision of Somalia's first Anglophone writer, Farah has written about Somalia and Somali characters for most of his career. Several decades of diasporic separation have not weakened Farah's bond with Somalia and its people, just as almost fifty years of being away from Indian soil has not dimmed his memory of the people there.

His time as a graduate student at the Government College of Panjab University might have gone unnoticed had he not written his debut novel during his stay on this campus and later become one of the leading African writers of his generation. Those who knew him at the time would probably not have guessed that he would return to the campus at the age of seventy-two to receive an honorary doctorate from Panjab University in 2017. His success as a writer is often ascribed to two 'immature' decisions that he made. The first decision concerns his choice to enroll at Panjab University in India rather than take up a scholarship to study at the University of Wisconsin-Madison

Asis De is associate professor of English at Mahishadal Raj College, West Bengal, India, and has published extensively on transculturality, diaspora studies and ecological humanities in Anglophone literatures.

Email: ademr@ggmail.com

(D) https://orcid.org/0000-0002-8018-4940

DOl: dx.doi.org/10.17159/2309-9070/tvl.v.57il.8059

DATES:

Submitted: 27 May 2019; Accepted: 4 July 2019; Published: 28 April 2020 
in the USA. Many scholars and Euro-American critics of Farah consider this one of the most whimsical decisions he has ever taken. His contemporaries from other African countries (Farah is usually considered to be the first Somali Anglophone writer) like Ngũgĩ, Emecheta, Armah or slightly more senior African writers like Achebe and Soyinka chose to move to the UK or the east coast of the USA as their first diasporic destination. The decision by this young Somali to go to India thus seemed foolish. In the course of this article, I will argue that this was not an 'immature' or whimsical decision but a well-thought-out, politically correct and wise decision in the global context of international relationships in the 1960s. The second decision considered immature by some was taken during Farah's stay in India. Whereas the established African writers mentioned above wrote on serious issues like independence realpolitik (postcolonial studies did not exist as a theoretical discipline then), African nationalism, African cultural identity and even psychological decolonization, this young Somali's debut novel explored the 'trivial' issue of marginality and liberation of women from a feminist perspective. His choice of subject matter may appear 'immature' in the scenario of African literature at the time, but I argue that Farah's choice should be seen in a different light. I show that were it not for his Indian experience, he might never have written From a Crooked Rib, a novel that has secured a place for him in the African literary scene as the "leading African writer of feminist consciousness" (Ngũgĩ's phrasing in the nomination for the Neustadt International Prize for Literature).

In 1969, after a four-year stay in India, Farah returned to Somalia with his Indian wife and the manuscript of his first novel, From a Crooked Rib. This was the year Muhammed Siyad Barre, a major general of the Supreme Revolutionary Council of Somalia, came to power following a coup d'état after the Somali President Abdirashid Ali Sharmarke was shot by a member of the armed forces. The country moved through chaotic, post-coup transitions, but gradually adopted scientific socialism as its political and economic base. During Barre's early years of military rule, some positive changes were made such as the modernization of industries and the nationalization of banks and most importantly, the standardization and promotion of Somali as the official language of Somalia. Initially, there was no evident animosity between Farah and the new leaders. However, their increasingly autocratic action made Farah worry about the future of the country. He decided to leave the country to do a master's degree in theatre studies at the University of Essex. He began writing his second novel there, which was set in the context of post-revolutionary Somalia in the mid-1970s. The news that Farah was portraying current Somali life in a harsh light in his new novel reached Barre in no time. Because of Barre's furious response, Farah was warned not to return to Somalia. His second novel, A Naked Needle (1976), was subsequently banned in Somalia. He was compelled to live in exile outside the geopolitical borders of Somalia until 1996, twenty-two years in total. This not only because of the danger Barre's despotic regime posed to him, but also because of the civil war that ensued when Barre fled the country in 1991. Even though "Farah's travels and tenancies-in Europe, North America, India, and (since 1981) seven African countries-have given him access to many diverse communities, cultures and ideas" (Wright xv), Nuruddin Farah remains a located cosmopolitan voice still spinning his yarns to keep his "country alive by writing about it" (Jaggi n. p.).

A "wanderer through the world's literatures" (Wright xvi) writing ceaselessly on the people and places of Somalia "both as object of the operation of power and subject of transformation" (Moolla 187), Farah is culturally a nomad who has settled in Cape Town, not as an exile but as a diasporic writer of Somali ethnic origin. It is not his ethnic connection with a nomadic pastoralist clan of Somalia that makes me see Farah as a nomad figure, but his belief in the imaginative relationship between mobility and liberty, his stateless status and his belief that society can be transformed by eradicating the traditional differences between the socio-cultural power structure of a community and the subject-position of an individual. Farah's constant quest for freedom and his desire to uphold values like equity, justice and rights, secularism and openness of mind, particularly in depicting the emancipation of women of an underprivileged, economically underdeveloped nation with a complex colonial history, have given him a unique status among the diasporic African Anglophone littérateurs. Though Somali people from the Horn of Africa occupy the central presence in Farah's works, Fiona Moolla observes that Farah negotiates a position through his art that enables him to find "his home 'everywhere" (189). In subscribing to this proposition, I wish to emphasize both Farah's borderless, geo-cultural approach to people and their histories in his fictional works, and his personal nomadic experiences across countries and cultures, even though conceptually a nomad lacks a settled 'home' rooted in a particular geopolitical origin.

The scholarly approach in this essay is largely biographical in that it focuses on Farah's student years in India (1966-69). The study also enquires into the socio-cultural influence India had on Farah's life and fictional works. In a number of interviews Farah seems to disavow that his 'Indian phase' had any particular importance 
as opposed to his diasporic experiences in other countries. This article considers Farah's 'Indian experience' as noteworthy not for the simple reason that this "period saw his marriage and the birth of his son Koschin", but also for the reason that these "four years of study at Chandigarh [...] helped to determine his choice of English as the language of his first novel" (Moore 4). ${ }^{1}$ In a more recent essay entitled "Ibsen, In Other Words", Farah acknowledges how his stay in Chandigarh, especially while he was studying at Panjab University, helped him to develop a taste for literature and to become a voracious reader. He admits in the essay, "I felt like a child in a candy store hungering after the sweets he knew he couldn't have" (15) until he met a "female fellow student" (15) who introduced him to the plays of Henrik Ibsen. She directed his attention to the play, A Doll's House. Before this, Farah was like a "lost child" (15) who was utterly bewildered when selecting a proper book from the shelves of the library: "I had admitted that I had no inkling which of the thousands of books written in a babble of tongues I should borrow and immerse myself in: Samuel Beckett, Virginia Woolf, Albert Camus, one of the Bronte sisters, William Faulkner, Simone de Beauvoir or Rabindranath Tagore" (15). Without a doubt, this Indian phase shaped the genesis of Somalia's first Anglophone writer of international repute. Farah's brief association with Indian culture, and his gaining of knowledge of Indian philosophy and literature, and, perhaps, of the secular aspirations of the dominant Indian politics of the time contributed to the young writer becoming firmly opposed to religious intolerance. Moreover, during his stay in India, Farah met eminent writers like Anita Desai and Ruth Prawer Jhabvala, who, as he recollects, "were all kind", but, more importantly, were deeply inspiring: "Ruth Jhabvala lent me the first book by an African writer that I read, Achebe's No Longer at Ease, and then said to me, 'If you're interested in writing, that's it.' This would have been 1968 when I first read a novel by an African south of the Sahara" (Alden and Tremain 36). Farah adds in the essay about being introduced to Ibsen while in India: "I've always written my significant works in relation to other works, glad that I could piggyback on other writers and forge my own ideas out of the smithy of the ideas garnered from them" ("Ibsen" 19).

If reading Achebe's No Longer at Ease in India in the early days of his career provided Farah with sufficient confidence to have his first novel, From a Crooked Rib, published, it is Ibsen's A Doll's House that served "as a point of reference as well as a fountain of inspiration" ("Ibsen" 16) for his first novel. This emerges clearly when Farah candidly confesses: "I could not have written From a Crooked Rib if I had not read A Doll's House" ("Ibsen" 17). In a recent interview published in the same issue of Tydskrifvir Letterkunde in which this essay appears, Farah suggests that his interest lay "in creating some kind of a bridge between Africa and Asia" rather than "creating a bridge between America and Africa," which makes him feel an "attachment to India" even today: "The greater benefit that I received from my presence in India for four years is the patience towards work, is the communal commitment that people have towards one another, and the fact that India as a subcontinent contains the world! There is no country like India. I still go there" (Farah and Moolla 19). In the same interview, Farah indicates that he turned down an American scholarship and chose to go to Panjab University instead because he was interested in the cultural pluralism of India (19). Farah's initial engagements are eastward with India, compared to the 'usual' westward engagement of contemporary, senior African writers like Ngũgĩ or Soyinka and Achebe to London and the eastern coast of the USA. Farah's uniqueness lies not just in his signature literary treatment of feminist consciousness and women's marginality, but in his singular choice to go to the other side of the globe to learn what 'communal commitment' means.

Farah's decision to come to India for higher education, rejecting the option of an American scholarship to the University of Wisconsin-Madison, may seem immature and even quite eccentric to aspiring young writers or scholars today. But, in the Somalia of the late 1960s, it was a 'politically correct' decision. Since gaining its independence from the colonial rule of Britain and Italy in July 1960, the government of the Republic of Somalia has had economic and military ties with the Soviet Union:

The growth of Soviet influence in Somalia dated from 1962, when Moscow agreed to provide loans to finance the training and equipping of the armed forces. By the late 1960s, about 300 Soviet military personnel were serving as advisers to the Somali forces [...] about 500 Somalis received military training in the Soviet Union. [...] The Soviet Union also provided non-military assistance, including technical training scholarships, printing presses, broadcasting equipment for the government, and agricultural and industrial development aid. (Metz 30)

On the other hand, the USA's continued support of Ethiopia, Somalia's hostile neighbor, could not have endeared it to a young Somali. The intensification of the Cold War and the consequent anti-communist policies of the United States in the early 1960s made the political relationship between the USA and Somalia even tenser. Opting 
to take up a scholarship to study at an American university may not have been a politically wise decision. By contrast, the Indian political scenario in the late 1960s probably seemed more acceptable as India was still following the Nehruvian model of a socialist economy. As far as international political relationships were concerned, India was on very friendly diplomatic terms with the Soviet Union as was Somalia. The political relationship between India and Somalia was also quite good in the 1960s. The Prime Minister of Somalia, Dr. Abdirashid Ali Sharmarke, along with the Minister of Information, visited India for the first time in 1963, and again in 1968 when he became the President of Somalia. So, however foolish or eccentric it may appear today, it was quite common in the Somalia of the 1960s for a young Somali to go to India to do a degree.

Leaving aside the political issues, I now concentrate on some literary and philosophical dimensions that might validate Farah's decision to go to India instead of the USA. In an interview with the eminent American philosopher Kwame Anthony Appiah at the New York Public Library in 2007, Farah comments that reading Somerset Maugham's novel The Razor's Edge (1944) and Chemmeen (1956) by the legendary Jnanpith-winning Indian (Malayalam) novelist Thakazhi Sivasankara Pillai in his teens, substantially influenced his decision to choose India, rather than the USA, as his first diasporic destination (Appiah, "Princeton Professor K. Anthony Appiah interviewed African novelist Nuruddin Farah about his recently released novel, Knots"). In reply to the question asked by the narrator-protagonist in Maugham's novel: "What made you go to India in the first place?" (266), the fictional character Laurence Darrell, the American from Illinois who had the experience of spending a little more than three years in India, answers: "Chance" (267), and "an intense conviction that India has something to give me that I had to have" (283). It is possible that Farah's logic was strikingly similar to that of Larry Darrell in Maugham's novel. In reply to the identical question: "What brought you to India?" posed by Professor Rumina Sethi of Panjab University in a programme hosted by the Department of English on 28 March 2017, Farah replied that before he decided to leave Somalia for India more than fifty years before, he had thought "to come to India and to spend three-four years in India will be a once-in-a-lifetime option. So, I took that option" (Sethi). Farah also tells Sethi that he wanted "to feel the pulse [...] to learn from the experience on a daily basis and therefore, turn that treasure into something worthy of reading" (Sethi). This urge "to feel the pulse" of Indian life and the desire "to learn from the experience" of Indian people is probably the result of reading the English translation of Pillai's Chemmeen, a novel that describes the love story of a low-caste Hindu fisherman's daughter, Karuthamma, and her Muslim lover, Pareekutty, a local fish trader, in the context of a poverty-stricken coastal hamlet of Kerala in India ${ }^{2}$. The novel seems to fascinate Farah not so much for its treatment of communal issues, but probably more for its representation of the local cultural tradition regarding women's chastity in a peripheral fishing community of India: if a married woman is unfaithful while her husband is at sea, the mythical sea-goddess Kadalamma would consume him. ${ }^{3}$ The way in which a society restricts its people's choices, particularly women's personal choices using an age-old religious 'superstition' and the double-standard of condemning women's infidelity, while it is silent on patriarchal domination, maltreatment and violence, is the basic issue that Chemmeen addresses. Is this not the message in Farah's first novel, From a Crooked Rib, which he wrote during his stay in Chandigarh? Possibly the desire to present the plight of women in peripheral societies and the urge to voice a literary protest against the 'traditional' practice of silencing women in the domestic space of the family became more powerful after the aspiring writer read Pillai's novel Chemmeen.

In Pillai's narrative, Karuthamma, the heroine of Chemmeen, cannot escape her arranged marriage with the local fisherman Palani, and is forced to sacrifice her love for Pareekutty. But, when she later finds Pareekutty standing on the doorstep of her hut, she cannot resist her long-suppressed desire for her lover, and thus violates the tradition of remaining true to her husband. Palani is at sea. His life, like those of Pareekutty and Karuthamma, ends tragically that very night as a result of a thunderstorm. The bodies of the lovers, still in close embrace, are found on the shore next morning. The death of Karuthamma is without dignity. Pillai the novelist reflects this in the title of his novel Chemmeen, meaning 'small sea-prawn' in Malayalam. It is just feasible that this Indian novel in translation caused Farah sufficient pain to make him consider writing on the issue of the desires of poor and peripheral women and their quests for individual identity. This was probably intensified by his sojourn in India and his personal experiences with Indian people, particularly women. The necessity to respect women's dignity, however peripheral and poor they may be, the issue of women's individual identity and empowerment, and the contribution of women to the lives of men, find expression in every novel of Farah. I have little doubt that Farah decided to make feminist consciousness a major issue in his writing while he was in India. At this point in the discussion of the issues of power and individual identity of women, I cannot but draw attention to a political 
connection, however flimsy and conjectural my argument may appear. Throughout Farah's four-year stay in India, Indira Gandhi, the daughter of India's first Prime Minister Jawaharlal Nehru, was the Prime Minister. Although what Farah wrote during his stay in India is patently a work of fiction that depicts a peripheral woman's struggle for identity, there is some justification for seeing the hopeful image of a strong, empowered Indian woman as Farah's motivation for depicting Ebla's liberation.

Farah's first novel, From a Crooked Rib, centers on the story of Ebla, an eighteen-year-old Somali girl, who runs away from home after she discovers that her grandfather has promised her in marriage to Giumaleh, a man of forty-eight. Ebla first escapes from her nomadic community to a nearby village, and then moves to the town. During her stay in the town, she discovers that her cousin has arranged her marriage to another man. She decides to find her own husband and flees to another city with a man she met only a few days earlier. After only seven days of marriage, she finds herself feeling despondent when Awill, her husband, tells her of his forthcoming assignment in Italy. In the city of Mogadishu, Ebla befriends a lady called Asha in the same apartment block. After a few days, she learns that her husband has had an affair with an Italian woman. It is Asha who convinces Ebla to take revenge on Awill by marrying someone else. Ebla marries a man named Tiffo, who does not tell Ebla about his wife and children. When Ebla finds out about Tiffo's family and realizes that she is nothing but his mistress, she recognizes that she needs to take control of her own life and regain her dignity as a woman. She seeks a divorce from Tiffo and breaks with Asha before Awill returns to Mogadishu from Italy. The narrative ends with the projection of Ebla and Awill (though husband and wife) locked in conjugal embrace: "[T] hey got under the same cover and Ebla wondered if tomorrow's sun would rise with happiness [...] and welcome his hot and warm world into her cool and calm kingdom" (162-3). Ebla also resembles Karuthamma, the heroine of Pillai's novel Chemmeen, in her sexual indulgence with Tiffo, while Awill, her husband, was away across the sea in Italy on a teaching assignment. A question arises at this juncture regarding how one can connect Ibsen's A Doll's House, which had a major influence on Farah and his first novel, From a Crooked Rib. Although Farah was immensely fascinated by Nora's character and her bold dialogues in A Doll's House, somewhere he felt that imitating Nora's personality would hamper the portrayal of his "Somali, nomad girl, an African and a Muslim" ("Ibsen" 17), the character Ebla, rather than substantiating it. Unlike Nora, who as a Norwegian housewife can slam the door "on her society and tradition, and tell her husband off" (17), Ebla has no "door to slam—nomadic huts have no doors of which to speak; only a cloth discreetly serving as a door" (17). But Farah also agrees that Nora and Ebla have one thing in common: "Both are strong-minded women" (17). It seems that the differences Farah identified while reading and re-reading Ibsen's play, actually enabled him to understand the way Ibsen had dealt with 'realism' in his play. This understanding helped Farah to depict the socio-cultural reality of a Somali woman in his first novel. In his essay "Ibsen, In Other Words", Farah clearly differentiates between Ebla's reality and that of Nora's: "But like Nora, Ebla wouldn't be comfortable with the generic identity in which a woman in Somalia is addressed with the derisory word intended as a put-down: 'Naayaa!' - meaning 'Hey you woman!'”(21).

It is no coincidence that Farah's Ebla resembles the Indian character Karuthamma in many respects. Moreover, the fictional character of the 'savant' (close to the idea of the 'Sant' or the Holy Man in India) in Mogadishu, as Farah depicts him in From a Crooked Rib (chapter 26), resembles an Indian Sikh: "The man had a thick beard, untrimmed but combed nicely with the wooden comb which he had on his head: he looked like an Indian Sikh" (134). ${ }^{3}$ A prominent female character in From a Crooked Rib is Asha, a common name in India. The meaning of 'Asha' in India is 'hope, or even 'hopefulness', which in the context of Farah's novel becomes implicitly connected with a hope for freedom (though at the expense of her reputation) from traditional feminine subservience in Somalia. It is Asha, who makes Ebla "aware" that hoping for freedom and equality is possible: "Ebla could not help being fond of Asha [...] she made Ebla aware of what she was" (109). The post-Partition trauma of a conflict-torn, north-western India can be compared with the violence and horrific activities in civil war-torn Somalia, as represented in the novel Secrets. The repeated references to famine and the scarcity of food, not only in From a Crooked Rib, but also in Farah's later novels, most particularly in Gifts, may remind the reader that, like Somalia, India was a country hit by food shortages and famine when Farah visited and stayed at Chandigarh. In the light of this it seems significant that Farah maintains a strange silence about the 'Green Revolution' that was taking place in the late 1960s India when Punjab was its center. To the son of a pastoralist, a writer who has childhood memories of farm-life, the prominent agrarian movement that helped India greatly increase crop production and farming was of great interest. Farah also found the issue of 'family planning' and its campaign very interesting. Farah tells Sethi in the interview, that he had been commissioned by the All India Radio (Chandigarh unit) to write stories on 
family planning. ${ }^{4}$ John C. Hawley-one of the ablest critics of Farah, observes Deeriye's defiance in Close Sesame (1983) as quite "akin to conscientious objection, a Gandhian nonviolent resistance and refusal to cooperate with the imposing power" (193), despite his active political past when he was intensely involved in the anti-colonial movements against the Italian occupation. As Appiah observes in his appreciation of Farah's writing, "[w]riting is always more about identification than identity" (n. p.). Exploring the 'Indian experience' in Farah's life and works depends more on historical identification, where the question of a single national identity seems to be limited. If the Eurocentric notion of ethnic identity implies a stasis rooted in a specific geopolitical base, then Farah certainly belies it as a writer with a geocultural approach to feminist consciousness.

In Links (2003), there are several references to the Indian cultural space in relation to the female character Miss Mira Meerut, a diasporic of Indian ethnic origin, who visits Mogadishu as a UNICEF consultant: "[S]he was from southern India, culturally speaking [...] her parents had migrated from Gujarat, in western India" (129). The very spontaneous comparison of Seamus's beard with that of a "devout Sikh [...] on a Guru's remembrance day" (131) substantiates Farah's easy cultural movements across time to his past everyday experience of finding bearded Sikhs in Chandigarh. Farah has lived in as many as six countries of Africa, each being a unique cultural unit; in Italy and short term stays in other European countries like Norway and Ireland and in India as a student and as an aspirant writer. But he remains culturally rooted in Somalia and in no way has dissociated himself from the socio-political spaces of Somali people, either inside the country, or in diasporic condition. While it is true that in many interviews (see Gray; Alden and Tremaine; Jaggi; Appiah; Farah and Moolla), Farah does not ascribe any particular importance to his Indian phase in relation to his literary oeuvre, it is quite clear that India is often injected into the experiences of many of his fictional characters. It is also interesting to note that some minor characters of Indian ethnic origin who appear in his novels, are all women and at the same time, diasporic.

Hiding in Plain Sight (2014) is a novel in which the character Padmini, like Mira Meerut in Links, is of Indian ethnic origin. Though Padmini was born in Uganda, her family members belong to a diasporic Indian merchant-community known as the "Dukawallahs"-the "small-business men and shopkeepers hailing principally from the Indian subcontinent" (71). Named after "the famous actress"(Hiding 73) of India, Padmini is shown as being in a "partnership as being on a par with marriage" (74) with Valerie after her failed "arranged marriage" to an Indian called Rajiv. ${ }^{5}$ The reference to Padmini and Valerie's movement to the Indian city of Pondicherry, famous for its association with Sri Aurobindo, is another link between the narrative and the Indian space of spirituality. The references to Valerie wearing cotton multi-colored "sari", the "Indian restaurant called Tandoori House", to the Sanskrit word "Nirvana", to the Indian way of saying "namaste", and to Indian cuisine- "chicken tandoori, plus a fish curry and a rich array of vegetarian dishes, including lentils, chickpeas, and an assortment of Indian finger foods" (Hiding 186) remind the reader of Farah's close association with knowledge of Indian culture and cuisine. In his highly engaging book The Long Space: Transnationalism and Postcolonial Form, Peter Hitchcock asserts that the "borders of the individual and that of a culture are less the sign of exclusion but of socialization itself" (92), and this is what happens in Hiding in Plain Sight, as Farah's representation of Indian culture, though quite exotopic, appears integral and sufficiently socialized. In the final chapter of the narrative, as Padmini talks about the multicultural and cosmopolitan nature of Indian society, the reader apprehends that it is Farah's own impression of India which he expresses through one of his major fictional characters: "India has suffered a great number of invasions. [...] It is a subcontinent with an ancient civilization, a huge population, and diverse cultures and faiths. I would say the cuisine reflects this multiculturalism. India boasts cosmopolitanism far beyond that of many countries in Europe, including England" (186).

The words and phrases Padmini utters in Hiding in Plain Sight such as "an ancient civilization" (181), "diverse cultures and faiths", "multiculturalism" and above all, "cosmopolitanism far beyond that of many countries in Europe" may appear to be Padmini's personal compliments to the country of her ethnic origin. However, these phrases collectively emphasize Farah's own impression of India even before his first arrival in India for graduate studies in the late 1960s. Quite similar to the character of Larry Darrell in Maugham's novel The Razor's Edge, it becomes clear, that Farah was fascinated by the spiritual but secular, multicultural but cosmopolitan, diverse but unified nature of Indian culture. Farah's novels are aesthetic responses to the ambiguities of life at large and individual identity. Jacqueline Bardolph observes in one of her deeply engaging commentaries on his works: "this African writer does not oppose modernity and superstition, but looks for coherence, complementarity, an on-going creativity in the effort to understand the world" (171). 
Derek Wright, a penetrating critic of Farah's work, views his literary oeuvre as a kind of "nomadic fiction, drawing upon many cultural and religious sources and upon readings in many of the world's literatures" (176). Beginning with the Indian cultural scenario and literature in his early twenties, Farah has travelled widely and taken up temporary residence in several countries of Africa, Europe and America, sometimes voluntarily, sometimes due to political circumstances. Through experiencing other people's cultures, Farah the novelist with Somalia in his heart, has been able to place his own ethnic culture and people in a much wider frame. Farah is a different kind of nomad, not in the sense of being a representative of the Somali pastoralist clan, but as someone who wishes to learn about other countries and their people by staying there. He acquires first-hand experience, and then uses his creative imagination to fill the spaces with Somali people and their transforming culture spaces. What makes his approach unique is that Farah does not attempt closely to capture the historical, political and cultural details of the places to which he travels and in which he stays, but he is meticulous about the representation of the Somalis, their culture and their relation to people of other ethnic groups. It is a fact that he spent more than three years studying in India. He married an Indian woman and even wrote the manuscript of his first novel there, but it is also true that he carefully omitted any depiction of contemporary India in that novel. It is equally true that he did not incorporate any penetrating depiction of the historico-political reality of Apartheid in South Africa although he has been based in South Africa for about two decades (since 1999, with his second wife Amina Mama and two children). In response to a question posed by Stephen Gray: "How do you take to being called the world's most famous nomad?", Farah replied: "I don't know if I'm a nomad as much as a mover-about [...] my movements have been in all directions and quite often decided by me - well, occasionally by other, political forces" (133). A global writer by temperament, Farah has shown no particular attachment to any country other than Somalia, whether he inhabits that country for some time, or travels there on a short visit. Though Hiding in Plain Sight (2014) is set in Kenya, North of Dawn (2018) is set in Norway, and the forthcoming novel is to be set in Johannesburg in South Africa, Farah's concern is with the cultural spaces of diasporic or refugee Somalis inhabiting those places and their relationships with people of other ethnicities, in examining the transformation of the present-day Somalis living beyond the geopolitical border of Somalia. In an interview with Appiah in 2007, Farah explains his stand on being a global writer quite explicitly. While complimenting Farah on having "a huge, worldwide audience", Appiah added, "You've made Somalia a real place for people who otherwise would never have thought about Somalia except for what they hear on the news from time to time". Farah responded in his uniquely sensitive and perceptive manner:

In my cynical way, I say that the world needs a Somali, a Ghanaian, a Frenchman, a Mexican, a Chinese and an Indian - to mention a few writers from these nationalities. There is a party to which the world invites one or two people from each place. I am the Somali invited to this party, and you are perhaps the Ghanaian. That's why you and I are who we areworld writers. (Appiah, "Princeton Professor")

My discussion in this article explores Farah's writing during four years of his life that have not hitherto enjoyed scholarly interest. The Indian experience reflected in Nuruddin Farah's literary oeuvre is far more extensive than a handful of references to Indian people or the cultural dimensions in the novels. It has made Farah a leading postcolonial voice in world literature. It is at an Indian university that he had the opportunity to read Ibsen's play A Doll's House, setting aside his earlier reading of the English translation of Pillai's novel Chemmeen. It seems more than mere conjecture that a politically conscious writer like Farah drew inspiration from the strong image of the Indian Prime Minister Indira Gandhi, while drafting his debut fiction on the issue of the liberation and restoration of dignity of a Somali woman named Ebla. This male writer, who was a member of a pastoralist clan in a small Islamic country in Africa, writes from a feminist perspective. He focuses on the liberation of the poor and powerless women, on patriarchy and the violence men sometimes inflict upon women, on cross-cultural movements across countries. These are mysteries that continue to produce an ever-increasing readership marveling at a geocultural world writer beyond geopolitical borders or time.

\section{Notes}

1. Farah had met Chitra Muliyil (his first wife) in Chandigarh, where she was "a student from Bangalore". He appears to have had a very easy relationship with Muliyil's father: "her father and I played chess" (Jaggi). The name of Farah's son is known to every reader of Farah, as Koschin is the protagonist of Farah's second novel A Naked Needle (1976). In an interview with Patricia Alden and Louis Tremaine, while commenting on his days at Panjab University in Chandigarh, Farah admits: "All I remember is that I didn't think I learned much from the university. [...] But the only other thing 
I remember from university is that I was doing English literature at one point and taking a novel exam-there was a course [...] 'The English Novel'" (35).

2. An interesting similarity between Pillai and Farah: the story goes that the Indian novelist Pillai wrote Chemmeen in just 8 days, while Farah took 28 days to write From a Crooked Rib, from 19 March to 15 April, 1968. (Vetticad)

3. The "wooden comb" on the head of the 'savant' resembling "an Indian Sikh" in From a Crooked Rib is one of the five articles of faith (Five 'K's: Kesh [uncut hair], Kara [steel bracelet], Kanga [wooden comb], Kachera [cotton underwear] and Kirpan [ceremonious steel sword]) according to the religio-cultural practice of the Khalsa Sikhs in India.

4. When Farah was staying in India, the Fourth Five-Year Development Plan (1969-74) accelerated family planning efforts by establishing a separate Department of Family Planning within the Ministry of Health and Family Welfare. Naturally, new campaign strategies were adopted to bring the target of family planning to fruition. During my recent trip to Chandigarh in March, 2019, I visited the Chandigarh office of the All India Radio (now called Prasar Bharti), which purportedly had archival material on Farah's works. To my astonishment, the responsible officer informed me that documents related to the production and broadcasting history of a time fifty years back were not there. The explanation given was that the papers, which dated back to a pre-cyber age, had been burnt as useless rubbish that was taking up office space.

5. Padmini Ramachandran (1932-2006) was a famous Indian actress and dancer who performed in more than 250 Indian films. Later she settled in New Jersey with her physician husband and started a school of Indian classical dance known as the Padmini School of Fine Arts.

6. Padmini Ramachandran (1932-2006) was a famous Indian actress and dancer who performed in more than 250 Indian films. Later she settled in New Jersey with her physician husband and started a school of Indian classical dance known as the Padmini School of Fine Arts.

\section{Works Cited}

Alden, Patricia \& Louis Tremaine. "How Can We Talk of Democracy? An Interview with Nuruddin Farah." Emerging Perspectives on Nuruddin Farah, edited by Derek Wright. Africa World Press, 2002, pp. 25-46.

Appiah, Kwame Anthony. "For Nuruddin Farah." World Literature Today. vol. 72, no. 4, 1998. p. 703. DOI: https://doi. org/10.2307/40154254.

. "Princeton Professor K. Anthony Appiah interviewed African novelist Nuruddin Farah about his recently released novel, Knots." YouTube. 21 Feb. 2007, www.youtube.com/watch?v=jYlXh9hHK-E. Accessed 24 Apr. 2019.

Bardolph, Jacqueline. "Dreams and Identity in the Novels of Nuruddin Farah." Research in African Literatures vol. 29, no. 1, 1998, pp. 163-73.

Farah, Nuruddin. From a Crooked Rib. Penguin. 2006

Hiding in Plain Sight. Riverhead, 2014

"Ibsen, In Other Words." Nordlit vol. 34, 2015, pp. 15-22. DOI: https://doi.org/10.7557/13.3350.

"Why I Write". Emerging Perspectives on Nuruddin Farah, edited by Derek Wright. Africa World Press, 2002. pp. 1-13.

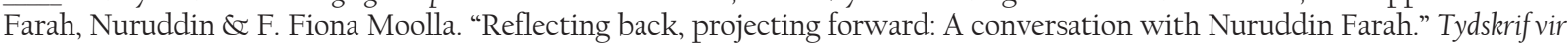
Letterkunde vol. 57, no. 1, 2020, pp. 19-25.

Gray, Stephen. "Interview with Nuruddin Farah." English in Africa vol. 27, no. 1, 2000, pp. 131-9. www.jstor.org/stable/40238895.

Jaggi, Maya. "Nuruddin Farah: A Life in Writing." The Guardian. 21 Sep. 2012, https://www.theguardian.com/culture/2012/ sep/21/nuruddin-salah-life-in-writing. Accessed 24 Apr. 2019.

Hawley, John C. "Nuruddin Farah-Tribalism, Orality, and Postcolonial Ultimate Reality and Meaning in Contemporary Somalia." Ultimate Reality and Meaning vol. 19, no. 3, 1996, pp. 189-205. DOI: https://doi.org/10.3138/uram.19.3.189.

Hitchcock, Peter. The Long Space: Transnationalism and Postcolonial Form. Stanford U P, 2010.

Metz, Helen Chapin. Somalia: A Country Study. Federal Research Division Library of Congress, 1993.

Moolla, F. Fiona. Reading Nuruddin Farah: The Individual, the Novel $\&$ the Idea of Home. James Currey, 2014.

Moore, Gerald. H. "Nomads and Feminists: The Novels of Nuruddin Farah." The International Fiction Review vol. 11, no. 1, 1984, pp. 3-12.

Samatar, Ahmed I. "Interview with Nuruddin Farah." Bildhaan: An International Journal of Somali Studies vol. 1, 2001, pp. 87-106.

Sethi, Rumina. "Rumina Sethi in conversation with Nurrudin Farah, Department of English, Panjab University." YouTube. 27 Apr. 2017. www.youtube.com/watch?v=1NxxpcDYOOA. Accessed 21 May 2019.

Vettica, Anna M. M. "Golden milestone." The Hindu BusinessLine. www.thehindubusinessline.com/blink/watch/goldenmilestone/article7899728.ece

Wright, Derek. "Parenting the Nation: Some Observations on Nuruddin Farah's Maps." College Literature vol. 19, no. 10, 1993, pp. $176-84$. 